\title{
Developing an Islamic-Based Leader Characters for 5 To 6 Years Old in Gorontalo
}

\author{
Pupung Puspa Ardini \\ Early Childhood Education Departemen, Gorontalo State University \\ Gorontalo, Indonesia
}

Corresponding e-mail: pupungpuspa@gmail.com

\begin{abstract}
This study aims to find out how the efforts of teachers in helping develop the character of the Islamic-based leader in Gorontalo. The focus of research include the efforts of teachers in helping develop the character of the Islamic-based leader, teachers strategies, and materials accordingly with children's ability and attract to learn while playing for 5-6 years old. This Scientific Study was conducted in September 2015 in Gorontalo. Qualitative studies in this research were conducted based on the study of observation, documentation, interviews and various literature related to the application of Islamicbased leader character for 5-6 years old. Data analysis used in this research is the developmental research sequence model of Spradley. Based on the results of research, In the first three months have not emphasized on learning about subject matter, but more emphasis on the formation of characters, especially the character of the Islamic leader and the process of internalization of the character itself. The Characters are courage (istiqamah), trusted (Siddiq), responsible (Amanah), Intelligent (Fathanah), and transmitter of information (tabligh). The strategies are some activities such as story telling, nasyid or singing Islami, tilawah, tahfidz, practice Adzan and Iqamah, practice to give speeches, manasic (ritual) of hajj, and practice to become the master of ceremony.
\end{abstract}

Keywords: character Islamic-based leader, children 5-6 years old

\section{INTRODUCTION}

Education is a majorfactor in forming the human person. Realizing that, the government is very serious, because with a good quality of education system, there is the quality generation in the future and able to adapt living in society, nation and state. Knowledge, Intelligent and dignified are not enough, but there are values that children must learn in order to become leaders in the future. These values must contain the concepts of honesty, trust, discipline, respect for others, empathy, mutual respect, selfcontrol, responsibility and justice. People generally know as "characters". Psychosocial development is also an effort for the children' nature to behave positively, the nature of tawhid, and keep the nature of the truth contained inside (Ar Rum ayat 30). Cultivation of the character should be given early, because, at this stage, children's brain develop $80 \%$ increasingly. In addition, according to Freud, that early childhood experience can form the personality of an individual permanently (Crain: 2007, 234).

The importance of inculcating leader character on early childhood was published in a scientific event in 2006 at the institute of education, The University of London in a scientific paper entitled effective leadership in the early year sector (ELEYS) study. In the paper mentioned that learning about the character of leaders in early childhood can improve the motivation and achievement of children in the future, because children are simply familiarized to make planning, setting at least for yourself. For example, create a schedule of activities in one day that will be done from waking up to sleep (Blatchford and Mani: 2006, 15). However, according to WHO and University of Wisconsin data in 2008 in a study, shows there are still $52.4 \%$ of children aged $6-9$ years who have not been able to take responsibility for daily activities (Ramawati, 2012: 89-91).

Education of Character is not only about manner but also education as leaders who have good morality in the future. The Leader is about the personality of the person whose can affect others and acts an important role in a relationship. This character can be developed in early childhood. Some important moral values are described in "Teach Values to Children" about the character of an Islamic leader, this book originally written by Richard Eyre in English and then translated in Arabic, while the contents are then perfected with the moral teachings contained in the Qur'an And the hadith of the Prophet Muhammad SAW. Finally, Their collaboration produced a book that contains about the values of Islamic character that can be applied to children. So that children can behave according to the character because of Allah SWT (Hard, 2011: 24).

The values of this character are in harmony with the values of the Islamic leader's character, among others, tabligh, amanah (belief-honest), siddiq, aqidah, courage, good social intercourse, moderate self-esteem, honor, keep promise, respect others, Love, giving priority to others, politeness, and justice. These values are examples of Prophet Muhammad SAW contained in the Qur'an and Hadith. Parents, teachers, and other adults around the 
children should be the model of the character. It is useless if it is merely an advice or a solicitation because the moral value learned from seeing, then imitated, and then can be internalized in the children (reinforced by reward) (Basya, 2011: 249).

Gorontalo is one of the provinces in Indonesia, on the island of Sulawesi. $99 \%$ of the population of Gorontalo are Muslims. This province has the philosophy of " "adat bersendikan syara', syara' bersendikan kitabullah". This philosophy has been formed approximately 400 years ago since the time of the kingdom of Gorontalo in the 17th century. This philosophy implies that the people of Gorontalo as a Muslim society live their daily life based on the religion adopted and the religion is Islam, based on Al-Qur'an. (Nur in Damis, 2017). Based on this Islamic philosophy can construct the form of leadership character (Barbuto Jr and Millard, 2012 : 234).

But in fact, there are cases of corrupt leaders. They use money that is not entitled to personal interests. This is rife in the mass media in Indonesia, the honesty (amanah) as a leader is still ignored (Amri Pradana, 2014). This has been proven through a prior investigation by the Commission of Corruption in Indonesia (KPK) and is currently in process in a corruption court. The rise of corruption cases in this country causes Indonesia to be included in the order of 114 corruption countries in the world.

Another case has recently taken place when the leaders of senator have not done their commitment to work for the people. Another improper attitude is when the opinion of a faction chairman is not heard because of a consensus or agreement, then he acts anarchically while presiding over the meeting. As a leader Should be able to accept the opinions of others according to the mutual agreement (Indra Akunto, , 2014).

Education of Character as a leader also deals with moral knowledge, moral feelings, and moral behavior. This implies that the character of a good leader consists of knowing good things, wanting good things, and doing good things. As a leader In early childhood, especially at the age of 5-6 years, Kohlberg's moral development is in the preconventional stage where Children understand the value of good and bad morality based on a system of punishment and respect controlled by the adult (Hilmansyah, 2014: 4-5).

This level is divided into two stages, the first, the stage of punishment and obedience, at this stage the child acts and responds to the physical consequences of a behavior, in other words, the child only judge the good and the bad based on the physical consequences or appreciation. At this stage, the children just obey the authoritarian figure to avoid punishment. The second is the Comparative Instrumentation orientation stage where the actions performed by the child are motivated by the satisfaction of the need. In addition, the child obeys the rules to gain an award or to fulfill personal goals. At this stage, the child begins to consider the interests of all parties when making moral judgments, but they still put their personal interests as children. $\mathrm{He} /$ she will be nice if others were being nice too (Lickona, 2013: 82).

This study was conducted in Kindergarten where the children are 5-6 years old. The reason for doing research in kindergarten because it brings many changes to the children's life. They begins to develop independence from the family, because of that is important. Activities like schools begin to bring these stage into regular interactions with the larger world. Friendships become more important, as well as physical, social, and mental skills develop rapidly. This is a critical stage for children to develop self-confidence in all areas of life, such as friendship, schools, and sports so that at this time the full potential of the child should be encouraged to develop maximally, especially the character of leadership (Morison And George in Nurani, 2012: 45).

Seeing the phenomenon in Indonesia in maintaining the character and identity of the nation as has been described previously, then the development of leader character especially in the preschool period needs to be done immediately. However, the fact that must be acknowledged is that the model of development of the right Islamic leader character has not been found substantially, therefore it is necessary to conduct a research to find the form of Islamic leader-based character building for children aged 5-6 years in kindergarten. The purpose of this research is to know the form and learning process in developing of Islamic-based leadership character on children aged 5-6 years in Gorontalo.

\section{METHOD}

This research used qualitative research method and case study approach, research process using "developmental research sequence" mode, and the steps are 1: (1) determine social situation of research, (2) carry out participant observation, (3) make field notes (7) conducting taxonomic analysis, (8) carrying out selected observations, (9) performing component analysis, (10) theme analysis, (4) conducting the analysis of the domains, 11) write cultural themes, and (12) write ethnography, thus referring to the data collection procedure by Spradley.

This research was conducted in Gorontalo, as one of the provinces in Indonesia which has the philosophy of " adat bersendikan syara', syara' bersendikan kitabullah "and $99 \%$ of the population are Muslims. The life philosophy is about Perform daily activities based on Islamic shari'a, based on AlQur'an and hadith. So it is famous as Madina foyer. The time of the research was conducted in the second semester of academic year 2014/2015. 


\section{RESULT}

Based on observations and interviews in some of the Islamic and State Kindergarten owned by the Government in September the values of Islamic leader character that is expected to be embedded in children such as tabligh, amanah (trust-honest), shidiq, brave, good social , Independent attitude, keeping honor, keeping promises, respecting others, love, giving priority to others, being polite and fair. These values are the example of Prophet Muhammad SAW.

Researchers observed for four months and students have shown some progress on self-reliance, environmental sensitivity such as cleaning up the classroom, throwing garbage in place, helping out, tolerance, willing to be imam, adzan without being forced during prayer time jama'ah or together in school, pray on time, and showing good social skills. This is reinforced by information provided by some teachers and parents of children who researchers encountered during the observations made. At that time some parents expressed joy when they saw positive developments in children within four months of schooling.

In the first three months have not been emphasized on learning materials, but more emphasis on the formation of characters, especially the character of the Islamic leader, especially the process of planting the character itself, not to the result. There is one day a week on a scheduled basis students are given practical and simple leadership lessons. Some activities or activities of Islamic leader characterization such as through storytelling, tahfidz the surah in juz 30, nasyid, tilawah, practice adzan and iqomah, giving speeches, manasik (ritual) Hajj and become a master of ceremony.

Table 1. Activities Program to develop Islamic-based leadership character on children 5-6 years old in Gorontalo.

\begin{tabular}{|c|c|c|c|c|}
\hline NO & Activities & Learning Method & Media & Time \\
\hline 1. & $\begin{array}{l}\text { Story } \\
\text { telling }\end{array}$ & $\begin{array}{l}\text { Practice directly to do } \\
\text { story telling about islamic } \\
\text { culture and history }\end{array}$ & $\begin{array}{l}\text { Books, } \\
\text { costume, } \\
\text { puppets }\end{array}$ & $\begin{array}{l}\text { Every day in } \\
\text { circle time }\end{array}$ \\
\hline 2. & Tahfidz & $\begin{array}{l}\text { Practice directly to surah } \\
\text { in Juz } 30 \text { together and } \\
\text { also individually }\end{array}$ & Children & $\begin{array}{c}\text { In the } \\
\text { morning } \\
\text { After play at } \\
\text { play ground } \\
\text { out side and } \\
\text { pray time } \\
\text { before } \\
\text { learning }\end{array}$ \\
\hline 3. & Nasyid & $\begin{array}{l}\text { Practice directly to sing } \\
\text { islamic song }\end{array}$ & $\begin{array}{l}\mathrm{CD} \text {, drum } \\
\text { band, } \\
\text { marawis } \\
\text { percussion }\end{array}$ & $\begin{array}{l}\text { In music and } \\
\text { movement } \\
\text { area or } \\
\text { center }\end{array}$ \\
\hline 4. & Tilawah & $\begin{array}{l}\text { Practice directly to read } \\
\text { Al-qur'an individually } \\
\text { and guided by teachers }\end{array}$ & Al-Qur'an & Every friday \\
\hline 5. & $\begin{array}{l}\text { Adzan and } \\
\text { Iqomah }\end{array}$ & $\begin{array}{l}\text { Practice directly adzan } \\
\text { and iqomah }\end{array}$ & children & $\begin{array}{c}\text { In pray area } \\
\text { or center }\end{array}$ \\
\hline 6. & Pidato & $\begin{array}{l}\text { Practice directly } \\
\text { individually }\end{array}$ & children & Every friday \\
\hline 7. & $\begin{array}{l}\text { Master of } \\
\text { Ceremony }\end{array}$ & $\begin{array}{l}\text { Practice directly } \\
\text { individually }\end{array}$ & children & Every friday \\
\hline 8 & $\begin{array}{l}\text { Manasik } \\
\text { (ritual) of } \\
\text { Hajj }\end{array}$ & $\begin{array}{l}\text { Practice directly together } \\
\text { with another school in } \\
\text { Gorontalo }\end{array}$ & $\begin{array}{l}\text { Children, } \\
\text { miniature of } \\
\text { ka'bah, } \\
\text { costume of } \\
\text { haij (ihram) }\end{array}$ & $\begin{array}{l}\text { Once every } \\
\text { year }\end{array}$ \\
\hline
\end{tabular}

\section{DISCUSSION}

\subsection{Forms of Islamic-based leadership character and learning process to develop Islamic-based leadership on children 5-6 years old in Gorontalo}

According to Lickona, the character of the leader is an operative value or value in action (Lickona, 2013: 81). In the other hand the process of character building in a child begins with the child's ability to judge something right, then cares about something right, and then does something that is believed to be true despite the many temptations from the outside or the environment. Lickona argues that the character of the leader is the possession of the good things like honesty, justice, courage, and affection in the lead. The Character is a good objective of human qualities affirmed in the cultural values of society and religion believed (Lickona, 2012: 13-16).

According to Rodd, the character of the leader is responsibility that requires attention to multiple roles, function and people in ways that align with and promote commitment to share values and vision (Rodd,2013:11). The character of the leader is the character of a person who is process oriented, the roles and responsibilities of two or more persons together in the pursuit of a common goal (Yusof, 2014 : 67). Involves the ability to create an environment that values commitment, challenge and growth, in which members of the team are encouraged and supported to realize their potential and provide the best. The best of leader characters that can be given to early childhood are: a) understand themselves, b) accept responsibility, c) build and communicated shared values and vision, d) inspire interest by living their values and vision, e) build trust, relationship, and cooperation among collegeaus, f) take action to realise goals of their own and the potential of their own.

According to Mc Call and Lawlor in Jones, et.all, the character of the leader must be visionary. Have many ideas and be able to communicate the idea to achieve the goal through many planning (2008: 1). Based on the opinion of Mc Call and Lawlor a leader must have the strong character such as Sense of responsibility towards the team and common goal but still have to be sensitive and flexible to Learn something new.

According to Rees, et.all leader characters are shared, distributive, collaborative, invitational, and collegiate ways of working (2010: 119). As a leader not only command your friends in teams while working but also should be able to do collaboration or cooperation to achieve goals. According to Ebbeck and Vaniganayake the character of the leader requires a positive sense of self of knowing our boundaries and our linkages (2005: 18). Leaders are 
not only concerned with leading a group or team alone but also leading themselves into a positive person.

According to Koesoema, the character of the leader is an individual character in a community that interacts with each other in building and developing their respective potentials in togetherness whose basic values are individual rewards as human beings who have freedom, uniqueness, and responsibility (2010: 306).

According to the theory of nature (Robbins and Judge, 2008: 50-55), the character of leaders is the leaders who have the nature of extraversion (like being near other people and showing themselves), consistent and open (creative and flexible), and have emotional intelligence. Meanwhile, according to behavioral theory, the character of the leader is the initial structure or ability to organize work, work relations, and goals, the subsequent behavior is considerate and intelligent interpersonal.

Based on some understanding of leader character can be concluded that the character of leader is character or traits possessed by a good leader, including: have clear vision and can communicate that vision to team work, then leader have sense of responsibility, care to team work, Flexible, then struggling to realize the vision that has been made(Ibrahim, 2012: 4332).

The character of the Islamic leader is the character of a leader which is the example of the great Prophet Muhammad SAW. As Al Qarni says, "This is the character among the characters of the Islamic leaders that the Prophet gave to mankind. This is a wise leader. This is a just leader "(Al Qarni, 2006: 59). Indeed in Islam a good leader is a leader who has at least four characters, namely siddiq (honest to be trusted), tabligh (transmitter or able to communicate and negotiate), amanah (responsible to carry out the task), fathanah (intelligent in planning Such as the vision, mission, and strategy to implement it).

Other exalted attributes of the Prophet are, istiqamah (understand the weaknesses and strengths of self before judging others (intelligent intrapersonal), wise, calm, patient, not forgetting the promise, fair, steadfast and tawakal. Done solely by faith in Allah SWT (Suliadi RS ,2011). As Jamil says, regarding some important features that describe The leadership of Islam, among them the first leader is bound allegiance to Allah SWT, the two leaders see the goals of the organization not only for the interests of the group but also in the scope of Islam widely, the third adheres to the Shari'a and morals of Islam, the fourth is amanah or consistent to the mandate (2015: 25).

According to Suwaidan, the character of an Islamic leader is "the character of a leader in accordance with transformational and situational leadership theory" according to a leader's transformation theory has four main tasks: first determining the desired mission and visionary, The mission must be communicated to colleagues or followers, the third is the realization of the leader's vision, the fourth improves the consistency of followers of the vision (As-Suwadian and Basyarahil, 2005: 94-101).Situational leadership theory explains that the character of a leader at some point may not necessarily be appropriate for another. This leader must be creative and flexible in every situation when leading.

There is new theory emerged in 1998 according to Meschan in Suwaidan about influential leaders regardless of circumstances, namely the theory of leadership qualities. These properties are motivated to direct others, personality, credibility, confidence, intelligence, problem mastering, self-control. In a conference in Kobe, there are several profiles of Islamic leader character, such as envisioning, ethicality, energizing (enabling the team) to be enthusiastic when the team Work), empowerment, excellence (2002: 75-76).

The forms of Islamic-based leadership character in developing an Islamic-based leadership spirit in children aged 5-6 years in kindergarten in Gorontalo is not much different from the character of the leader in general. The fundamental difference is that the character of an Islamic leader is an example of the Prophet Muhammad and all is done solely by faith in Allah SWT (Mahazan,2015 :723) . Some of the characteristics or traits of an Islamic-based leader include siddiq, tabligh, amanah, fathanah, istiqamah (stand firm, nurture or understand weaknesses and strengths before judging others (intelligent intrapersonal), wise, calm, patient, non-broken, Steadfast and tawakal.This supports several theories about the character of Islamic leaders

Leadership characters can be learned from books or leadership training, but being the best leader is not enough just to do those two things. Consistent leaders develop a commitment to behave immorally is a very long process and traced back from an early childhood. In this study was revealed about how parents build a child's character. Through a qualitative approach with in-depth interview method of eleven families. The child has two responses. The first child receives consciously and the second is not fully accompanied by consciousness. Children who receive consciously, the consistent behavior of children both at home and at school. While children who receive less accompanied awareness show inconsistencies in behavior when inside and outside the home (Asyanti and Lestari, 2012: 138-145).

Another study researched by Stamopoulos in Australia also supports the results of this study. About the characteristics of leaders that must be had in early childhood, including professional knowledge, the application of an interpretative lense, courage, and relational trust. The values that need to be inculcated are the knowledge of a good leader, applying various interpretations from different 
perspectives or being able to solve problems from different perspectives, courage, and determination, and can maintain trust with the team (2011: 11-13).

\subsection{Learning process to develop Islamic- based leadership character conducted by teachers in kindergarten in Gorontalo}

Development in early childhood will never be separated from the learning concepts that form the development itself. The essence of learning is a process of interaction. According to Gordon in Smith and Ragan, that learning is a process of interaction between teachers, students, and learning resources in a learning environment (Smith and Ragan, 2006: 150). While Glaser in Anderson, states learning is a bridge that connects between the learning objectives and characteristics of individual learners in school. The main purpose of learning is to design certain conditions that can help students achieve learning goals / competencies established by the school. The two most important tools in creating such conditions are time and learning materials (Anderson, 1989: 39). In addition, learning is also defined as a process that produces a relatively permanent change in the behavior and potential of one's behavior. These behavioral changes are the result of personal experience or the results of practice gained from the learning process.

The meaning of learning is confirmed by Conny R. Semiawan by discussing the three components that exist in the learning, the target group analysis (who learners are faced), content analysis (what the target program), and context analysis which means what relevance the program (context) and Related to it, what competencies are needed at the end of the program. So, according to Conny, learning in early childhood means what content needs to be given (content analysis) in order to change the behavior of the learners (target group analysis) covering the aspects of knowledge, skills, attitudes, and values, so it needs to be maintained curriculum Or an area of interest to be kept contextually and filter out the "flood of information" due to globalization (Semiawan, 2002: 6). A good learning process according to Suparman is a learning process that enables learners to actively engage themselves In the whole process both mentally and physically (Suparman, 1997: 40). In early childhood education, the learning process and activities take place in the teacher's assistance either as a facilitator, motivator, or inspired the students.

According to Morrison, Ross and Kemp in implementing the teaching and learning process teachers should design learning strategies by considering the following questions; (1) what is the best way to teach a fact, concept, rule, habit, procedure, interpersonal skill or an attitude ?, (2) how can a teacher make a meaningful lesson ?, (3) how a teacher can teach a Focusing on interpersonal skills ?, (4) what is the best way to demonstrate that each learner controls a predetermined goal. The lesson will have the meaning for the learner before it has done beforehand the learner's needs analysis, development goals, problems, strengths, weaknesses, and opportunities for the achievement of learning outcomes. All this is done in order to make the appropriate learning plan as expected (2001: 124).

The effectiveness of the designed learning strategy will ease the learning process. The learning process will run smoothly, if the components involved in learning activities such as teachers, and students interact with each other in accordance with the rules and objectives to be achieved. The objective formulation contains changes in students' potential multidimensional behavior. Learning is supported by selection and methods, appropriate media, instructional content, and evaluation in accordance with the objectives. Thus learning is a system that has learning components that interact with each other and start and go to the goal. Learning will not be effective without using a strategy. To create meaningful learning requires the adoption of appropriate strategies. Components that must exist in a learning strategy in order to achieve the goal effectively according to Suparman are (1) sequence of instructional activities, (2) instructional methods, (3) instructional media, (4) time used in instructional activities ( Suparman, 1997: 157). The opinions lead to a conclusion that learning is a process of interaction between teachers and students to get behavioral changes according to learning objectives that were previously prepared carefully in the form of lesson plans, where in the interaction teachers function as a facilitator, motivator / inspirator for children by Involving both physical and mental that will shape positive and tolerant attitudes toward diversity and life differences.

Moral development is a good or bad behavior of someone. morale is considered to be progressing if experienced a change towards quality. Moral development has three phases. The three phases of moral development according to Santrock include: (a) Mind, (b) Action, (c) Feelings (Lawrence, 1997: 269). The moral development has several dimensions. Dimensions of Moral Development according to Papalia are as follows: (a) intrapersonal, (b) interpersonal. Intrapersonal is the moral associated with regulating one's activity against the person's self. Interpersonal is the moral that governs social interaction and conflict resolution.

Early childhood, especially 5-6 years old, according to Kohlberg is at the pra conventional stage and purely egocentric or ego. At this stage, the child focuses on the direct consequences of the actions that the child perceives. For example, action will be considered morally wrong if the children get punished. Children do not understand that the other 
person's point of view is different from them to understand about moral (authoritarianism). This authoritarian attitude is also characterized by the child's right behavior is the most desirable behavior and all the actions are done only for him/herself. Based on the stage of moral development there are characteristics of moral development, children who can pass the tasks of development in the moral aspect based on these characteristics are in the flow of optimal development. According to Jarolimek based on Piaget and Kohlberg's theory, the characteristics of moral development of children aged 6-8 years are: (a) Children do good because they want to get praise, (c) children are able to adjust to social values in groups related to good and $\mathrm{Bad}$, (c) children begin to obey the demands or rules of parents and social environment (Jarolimek, 1986: 33). The basic theory of Islamic leader characterization is the theory of operant conditioning or operant conditioning is the theory of behavior change achieved as a result of learning through positive or negative reinforcement process.

Based on observations and interviews with the Institut Kindergarten institution in Gorontalo, the inculcation of Islamic-based leader values is done through habituation. Habituation programs are conducted directly and routinely by providing strengthening in the form of rewards and consequences for those who violate them. Some Islamic values-based leadership development programs include storytelling, tahfidz surah in Juz 30, nasheed, recitations, practicing adzan and iqomah, giving speeches, manasik (ritual) Hajj and becoming a master of ceremony.

\section{CONCLUSION}

The forms of Islamic-based leadership character in kindergarten for children 5-6 years old in Gorontalo is not much different from the character of the leader in general. The fundamental difference is that the character of an Islamic leader is an example of the Prophet Muhammad and all is done solely by faith in Allah SWT. Some of the characteristics or traits of an Islamic-based leader include, siddiq, tabligh, amanah, fathanah, istiqamah, has intrapersonal intelligence, wise, calm, patient, not lie, Steadfast and trustworthy. This supports several theories about the character of the Islamic leader. Children will do some responses. Firstly, the child is voluntary and the second is not entirely voluntary Children who receive them voluntarily, will behave well at home and at school. While the less voluntary children show inconsistent behavior when at home and outside.

Based on observations and interviews with the Kindergarten institution in Gorontalo, the inculcation of Islamic-based leader values is done through habituation. Habituation programs are conducted directly and routinely by providing strengthening in the form of rewards and consequences for those who violate them. Some Islamic values-based leadership development programs include storytelling, tahfidz, nasyid or singing Islamic, tilawah, adzan and iqomah, giving speeches, or becoming a master of ceremony.

Recommendations are directed to stakeholder: (1) head master, the leader of school will Organize programs that are more applicable and fun for children. (2) Teachers, as a reference to be someone who is responsible to educate the character of an Islamic leader for children 5-6 years old.

\section{REFERENCES}

[1] Al-Qur'an surat Ar Rum ayat 30

[2] Abdullah Al Qarni. Aidh. (2006). Sentuhan Spiritual Aid Al Qarni. Depok: Gema Insani.

[3] Afandi, Rifki. (2011). Integrasi Pendidikan Karakter Dalam Pembelajaran IPS di Sekolah Pedagogia. I, I.

[4] Akunto, Indra. (2014). Rakyat sudah "move on" ,DPR kapan? (www.kompas.com, 30 oktober 2014) diunduh pada 2 november 2014.

[5] Asyanti, Setia dan Lestari, Sri. (2011). Keluarga sebagai tonggak Penyemai Benih-pemimpin yang berkarakter tangguh. Temu Ilmiah Nasional Psikologi Islami III, Fakultas Psikologi Universitas Muhammadiyah Surakarta.

[6] Barbuto, John E.and.Millard, Michele L, (2012). Wisdom development of leaders. International Journal of leadership studies, 7, 2.

[7] Bertens. (2004). Etika. Jakarta: Gramedia.

[8] bin Jamil Zainu, Muhammad (2002). Solusi Pendidikan Anak Masa Kini, terjemahan oleh Syarif Hade. Jakarta: Mustaqim.

[9] Budimansyah, Dasim. (2002). Model Pembelajaran dan Penilaian Berbasis Portofolio. Bandung: Genesindo.

[10]Bungin, Burhan. (2007). Penelitian Kualitatif: Komunikasi, Ekonomi, Kebijakan Publik, dan Ilmu Sosial Lainnya. Jakarta: Kencana.

[11]Crain, William. (2007). Teori Perkembangan Konsep dan Aplikasi. Yogyakarta: Pustaka Pelajar. 
[12] Crain, William. (2007). Teori Perkembangan Konsep dan Aplikasi. Yogyakarta: Pustaka Pelajar.

[13]D. Sudjana S. (2000). Strategi Pembelajaran Pendidikan Luar Sekolah. Bandung: Falah Production, 2000.

[14]Dariyo, Agoes. (2007). Psikologi Perkembangan. Bandung: Refika Aditama.

[15] Dewantara, Ki Hajar. (2004). Bagian Pertama Pendidikan. Yogyakarta: Taman Siswa.

[16]Dick, Walter dan A. Reiser, Robert. (1989). Planning Effective Instruction. Boston: Allyn and Bacon.

[17]Ebbeck, Marjory dan Vaniganayake, Manjula, (2005). Early childhood Professionals: Leading Today and tomorrow. Australia: Mac Lennan and Petty.

[18]H. Baharrudin dan Nur Wahyuni. (2009). Esa Teori Belajar dan Pembelajaran.Yogyakarta: Ar-Ruzz Media.

[19] Hard, Louise. How is leadership understood and enacted within the field of early childhood education and care. Queennsland: Queendsland University of Technology.

[20]Hilmansyah, Hilman. (2014). Meneropong Karakter Lewat Golongan Darah?Nakita no 812/Th XVI/22-28 oktober 2008. Jakarta: Kompas Gramedia.

[21] Ibrahim, Mazlan, et.all. (2012). The concept of leadership from the perspective of Hamka. Journal of applied science reaserch, 8.

[22] Jamil, Muhammad Yousaf, (2015). Islamic Perspective of leadership. Journal of islamic thought and civilization, 5, II.

[23] Jarolimek, John. (1986). Social Studies in Elementary Education. Macmillan Publishing Company.

[24] Jones,et.all. (2008). Leadership and Management in the Early Years: From
Principles to practice. England: McGraw-Hill Education.

[25]Koesoema A. Doni. (2010). Pendidikan Karakter: Strategi Mendidik Anak di Zaman Global .Jakarta: Gramedia.

[26]Kohlberg, Lawrence. (1997). Tahap-tahap Perkembangan Moral. Jakarta: Kanisius.

[27]L. Smith, Patricia and J. Ragan. Tillman, The Impact of R.M. Gagne's Work on Instructional Theory. University of Oklahama. 2006.

[28]Lickona, Thomas (2012). Character Matters.terjemahan. Jakarta: Bumi Aksara.

[29]Lickona, Thomas. (2013). Educating for Character.terjemahan. Jakarta: Bumi Aksara.

[30] Mahazan A.M, et.all, (2015). Leadership behaviours in Islam. Middle east journal of scientific reaserch, 23.

[31] M. As-Suwaidan, Thariq dan Umar Basyarahil ,Faisal. (2005). Melahirkan Pemimpin Masa Depan. Jakarta: Gema Insani.

[32] Miels, Jill. (1999). The Seven Faces of The Early Childhood Educator. Department of Elementary Education.

[33]Miles, M.B.and. Huberman; A.M. (1984). Qualitative Data Analysis. USA: Sage Publications.

[34]Morrison, Gary R. I.et.all. (2001). Designing Effective Instruction. New York: John Wiley.

[35] Morrison, George S.dalam Yuliani Nurani. (2012). Konsep Dasar Pendidikan Anak Usia Dini. Jakarta: PT.INDEKS.

[36] Nurani Sujiono, Yuliani. (2009). Konsep Dasar Pendidikan Anak Usia Dini. Jakarta: Indeks.

[37]P.Robbins, Stephen dan A.Judge. Timothy (2008). Perilaku Organisasi. Jakarta: Salemba Empat.

[38]Papalia, Diane E.et.all. (2008). Human Development. Jakarta: Kencana Prenada Media Group. 
[39] Parker-Rees, Rod et.all. (2010). Early childhood studies. Britain: Learning Matters Ltd.

[40] Pidarta, Made. (1997). Landasan Kependidikan Ed.I. Jakarta: Rineka Cipta.

[41]Pradana, Amri. Korupsi yang merajalela, http://politik.kompasiana.com/2014/03/27 /korupsi-yang-merajalela-642444.html, 27 maret 2014, diunduh 22 November 2014

[42]R. Semiawan. Conny. (2002). Belajar dan Pembelajaran dalam Taraf Usia Dini. Jakarta: Prenhallindo.

[43] Rodd, Jillian. (2013). Leadership in Early Childhood. Sidney: Allen and Unwin.

[44] Santrock, John W. (2007). Perkembangan Anak. Jakarta: Erlangga.

[45] Satrock, J.W. (2007). Terjemahan. Perkembangan masa hidup. Jakarta: Erlangga.

[46] Siraj-Blatchford, Iram dan Mani,Effective, Laura. (2006). Leadership in the Early years sector (ELEYS) study, University of London.

[47] Stamopoulos, Elizabeth, (2011). Building Early Childhood Leadership.Reflections. Gowrie Australia, 44.

[48] Sudrajat, Akhmad "Pendidikan Karakter" http://akhmadsudrajat.wordpress.com/2010/08/2 0/pendidikan- karakter-di-smp/, diakses 26 November 2014.
[49] Suliadi,

RShttp://berkarya.um.ac.id/2011/05/pemimpinan -dan-kepemimpinan-menurut-islam/ diunduh pada 20 november 2014.

[50]Suparman, Atwi. (1997). Model-model Pembelajaran Interaktif. Jakarta: STIE LAN PRESS.

[51] Syah, Muhibin. (2003). Psikologi Pendidikan dengan Pendekatan Baru. Bandung: Remaja Rosdakarya.

[52] Syamsi Basya, Hassan. (2011). Mendidik Anak Zaman Kita. Jakarta: Penerbit Zaman.

[53]W. Anderson. (1989). Lorin The Affective Teacher-Study Guide and Readings. USA: McGraw-Hill Publishing Company.

[54] Yusof, Rorlinda. (2014). Ciri-ciri kepemimpinan Pelajar Pintar dan berbakat: Implikasi ke atas kepemimpinan remaja islam. International Journal of Islamic Thought, 6. (2002). Leadership and Unity in

Islam. United State of America: iUnivers Inc.

$[56]$ ,Undang-Undang Republik Indonesia

Nomor 20 Tahun 2003 tentang Sistem

Pendidikan Nasional .Bandung:

FOKUSMEDIA, 2006. 